\title{
A CRÍTICA DE JEREMY WALDRON AO CONSTITUCIONALISMO CONTEMPORÂNEO
}

\author{
JEREMY WALDRON'S CRITICISM TO CONTEMPORARY \\ CONSTITUTIONALISM
}

Cristina Foroni Consani*

\begin{abstract}
RESUMO: este artigo apresenta e discute a crítica de Jeremy Waldron ao constitucionalismo contemporâneo, notadamente, às teorias constitucionais que centralizam a discussão acerca da democracia constitucional na proteção aos direitos fundamentais e em sua retirada do debate político. Neste sentido são apresentadas, primeiramente, as teses constitucionalistas às quais Waldron se opõe. Num segundo momento, são apresentadas suas críticas às teses constitucionalistas, assim como suas propostas para compatibilização entre o ideal constitucional e a democracia. Por fim, realiza-se uma avaliação acerca dos limites de cada uma das teorias em discussão.
\end{abstract}

PALAVRAS-CHAVE: Constitucionalismo. Democracia. Jeremy Waldron.

ABSTRACT: This paper presents and discusses Jeremy Waldron's criticism of contemporary constitutionalism - namely against constitutional theories that focus the discussion of constitutional democracy on protection of fundamental rights and its withdrawal from the political debate. To these ends, first are presented the constitutional arguments that Waldron opposes, after which appear his criticisms of constitutionalist thesis, as well as his proposals for reconciling the constitutional ideal and democracy. Finally, will be made an assessment about the limits of each of the theories under discussion.

KEYWORDS: Constitutionalism. Democracy. Jeremy Waldron.

\section{INTRODUÇÃO}

Hodiernamente, historiadores do conceito de constituição têm apontado para uma acentuação da compreensão da constituição como uma norma jurídica, enfatizando a proteção aos direitos e relegando a um segundo plano os aspectos políticos que dizem respeito diretamente ao exercício da soberania popular. Isso se verifica sobretudo após a Segunda Guerra Mundial, quando praticamente todas as democracias ocidentais introduziram ou fortaleceram em suas constituições a jurisdição constitucional, cuja finalidade é funcionar como um mecanismo de proteção dos direitos fundamentais contra uma possível atuação

\footnotetext{
* Pós-doutoranda em Direito - UFRN / PNPD / CAPES. Doutora em Filosofia pela Universidade Federal de Santa Catarina (UFSC). Mestre em Direito pela Universidade Federal de Santa Catarina (UFSC). Pesquisadora vinculada ao NÉFIPO/UFSC (Núcleo de Ética e Filosofia Política).

Revista da Faculdade de Direito - UFPR, Curitiba, vol. 59, n. 2, p. 143-173, 2014.
} 
legislativa contrária a esses direitos. ${ }^{1}$

Isso tem acentuado a polarização, dentro da filosofia política, entre constitucionalismo e soberania popular, colocando em cena conceitos distintos de democracia. De um lado, os defensores do constitucionalismo sustentam que é impossível haver democracia sem que se estabeleçam limites ao exercício da soberania popular, uma vez que quando direitos e liberdades básicos não são respeitados, então o próprio ideal democrático também não o é. Por outro lado, defensores do ideal democrático sustentam que o estabelecimento de limites ao debate político por meio do entrincheiramento de direitos em constituições, e da consequente retirada desses temas da discussão, relegando a decisão a respeito desses temas para outras instituições, fere o princípio da soberania popular e isso, por sua vez, também afronta a própria democracia.

Neste artigo, apresentar-se-ão os principais argumentos desse debate, a partir do diálogo que se estabelece em torno da ideia de Constituição equiparada a um précompromisso, tendo, por um lado, Stephen Holmes, sustentando as teses constitucionalistas e, por outro, Jeremy Waldron, tecendo críticas a tais teses. Ao final, serão analisados os principais argumentos em debate a fim de apontar as vantagens e limites de cada um deles.

\section{O CONSTITUCIONALISMO E A SALVAGUARDA DOS DIREITOS FUNDAMENTAIS}

O ideal constitucionalista está relacionado à limitação do poder político. No debate contemporâneo, essa limitação dirige-se, sobretudo, à atuação legislativa, que é tomada como possível violadora de direitos fundamentais. Autores que se dedicam à história e ao conceito deste tema ressaltam seu aspecto de limitação ou restrição. Nesse sentido, McIlwain (2007, p. 21), em seu clássico estudo sobre a história do constitucionalismo, sustenta que em todas as fases do constitucionalismo o elemento que mais se destaca é a "limitação legal sobre o governo". Outras definições desse conceito, do mesmo modo, chamam a atenção para esse elemento. Gordon (1999, p. 5) sustenta que o termo constitucionalismo é usado "para denotar que o poder coercitivo do Estado é restringido". Sajó (1999, p. xiv) define o constitucionalismo como "um conjunto de princípios, modos e arranjos institucionais que foram usados tradicionalmente para limitar o governo" e que deve servir como "um limite à democracia funcionando descontroladamente". Dworkin (1995, p. 2) entende que o

\footnotetext{
${ }^{1}$ Não cabe aqui fazer uma reconstrução histórica das mudanças no conceito de constituição, mas apenas apontar para aspectos que assumem relevância na discussão atual. Para uma reconstrução histórica desse conceito ver: MOHNAUPT; GRIMM, 2008; FIORAVANTI, 2001; McILWAIN, 2007.

Revista da Faculdade de Direito - UFPR, Curitiba, vol. 59, n. 2, p. 143-173, 2014.
} 
constitucionalismo é "um sistema que institui direitos individuais legais que a legislatura dominante não tem poder para anular ou comprometer". ${ }^{2}$

Um dos modos que tem sido adotado para justificar a legitimidade das restrições constitucionais à soberania popular é o recurso à teoria do pré-compromisso, segundo a qual as limitações constitucionais são restrições autoimpostas e, por esta razão, não há comprometimento do elemento volitivo que confere legitimidade à retirada de alguns temas do debate político.

Desde os anos de 1960, quando Hayek (2011, p. 268) considerou que a constituição é um mecanismo que permite o "apelo do povo bêbado ao povo sóbrio", a ideia do précompromisso constitucional tem sido utilizada para indicar a harmonização destes dois ideais. No final dos anos de 1970 e durante as duas décadas seguintes, a ideia de pré-compromisso voltou ao centro do debate da filosofia constitucional com a comparação que se estabeleceu entre o pré-compromisso e o mito de Ulisses, retomada de Spinoza (1994) por Elster (1989) e também por Holmes (1988b).

Tal como o mito é narrado por Homero, Ulisses, em sua viagem de retorno para Ítaca, queria ouvir o canto das sereias. Mas tinha consciência de sua falibilidade ao ouvir a melodia; então, deu ordens bastante precisas à sua tripulação (que deveria estar com os ouvidos tapados) para atá-lo ao mastro de seu navio e não soltá-lo, nem mesmo se ele reformulasse sua intenção original e desse novas ordens. Deveria permanecer atado ao mastro até que se afastassem do perigo. Do mesmo modo, recorre-se à figura de uma pessoa sóbria que, antes de começar a beber, entrega a chave do carro para um amigo por saber que ao final da noite não terá discernimento para tomar a decisão mais prudente. Os exemplos de Ulisses e do bêbado se aproximam do ideal defendido pelo constitucionalismo quando estabelece que as normas constitucionais que protegem direitos, tendo sido estabelecidas por meio de decisões racionais, devem permanecer de fora da discussão política eventualmente realizada em momentos de comoção social ou falta de racionalidade.

Segundo Elster (1989, p. 160), “a estratégia de Ulisses consiste em comprometer as gerações posteriores estabelecendo uma constituição que inclua cláusulas que lhes impeçam de alterá-la facilmente". Holmes (1988b, p. 196), ao explicar essas metáforas, recorda que elas equiparam a constituição ao agente racional do seguinte modo:

A constituição é Pedro sóbrio enquanto o eleitorado é Pedro bêbado. Cidadãos precisam de uma constituição assim como Ulisses precisava ser atado ao seu mastro.

\footnotetext{
${ }^{2}$ Todas as traduções das obras citadas são da autora do artigo, salvo quando indicado diversamente.
} 
Se fosse permitido aos eleitores conseguir aquilo que desejam, eles inevitavelmente naufragariam. Ao vincular a si mesmos a normas rígidas, eles evitam tropeçar em seus próprios pés. ${ }^{3}$

Ao se analisar esta estratégia, percebe-se que ela reforça o caráter restritivo da constituição em termos de uma autolimitação, para afirmar que a tensão entre constituição e democracia, reconhecida por autores do constitucionalismo moderno como Jefferson e Madison, na realidade não existe, pois a constituição é uma limitação colocada pelo povo sobre si mesmo, cujas restrições são necessárias para assegurar o exercício da liberdade, dos antigos e dos modernos.

A assunção desta perspectiva está ancorada em determinadas concepções de constituição, povo e democracia, as quais serão analisadas a partir dos argumentos apresentados por Holmes. ${ }^{4}$ Partindo da tese apresentada por Ely (1997) em Democracy and Distrust ${ }^{5}$, segundo a qual as constituições e as restrições impostas ao debate político não são antidemocráticas, mas, ao contrário, reforçam a democracia, Holmes (1988b) assume uma postura que pode ser chamada de madisoniana, muito embora negue uma tensão que Madison certamente reconheceu. ${ }^{6}$

\subsection{CONSTITUIÇÃO}

Holmes, ao prefaciar o livro de Sajó (1999, p. x), define as constituições como “ordens de restrições gigantescas motivadas por uma paixão pela prevenção (...) impelidas pelo desejo de escapar de resultados políticos perigosos e desagradáveis". Alguns anos antes, Holmes (1988b) já havia assumido o posicionamento sustentado por Madison segundo o qual a constituição é um mecanismo que limita o poder, mas que também o cria e organiza as regras de seu funcionamento. Nesse sentido, o estabelecimento de um rol de temas inatingíveis pelas decisões populares, como os direitos e garantias fundamentais e procedimentais, é necessário para proteger o próprio processo de participação política. $\mathrm{O}$

\footnotetext{
${ }^{3}$ Este não é exatamente o enfoque dado por Holmes ao pré-compromisso constitucional, como se verá a seguir. $\mathrm{O}$ autor usa essa definição apenas para ilustrar como o tema é frequentemente abordado.

${ }^{4}$ A teoria de Holmes é tomada como exemplo porque apresenta de forma bastante clara o que se pode chamar de tese constitucionalista no que diz respeito à relação entre constituição e democracia, a saber, de que a democracia e a soberania popular devem ser limitadas a fim de proteger os direitos fundamentais.

${ }^{5}$ John Hart Ely, comumente apontado como o mais influente expoente da visão procedimentalista da democracia constitucional. Em um livro de 1980, Democracy and distrust: A theory of judicial review, ele critica o que chama de tese dos valores fundamentais de acordo com a qual as cortes constitucionais têm poderes para invalidar a legislação que infringe os princípios-chave consagrados na constituição.

${ }^{6} \mathrm{O}$ que se chama aqui de postura madisoniana é a desconfiança da ação popular na política sem instituições que promovam o devido controle e coloquem limites à participação de cidadãos ou representantes nas decisões coletivas.
}

Revista da Faculdade de Direito - UFPR, Curitiba, vol. 59, n. 2, p. 143-173, 2014. 
autor insere a discussão a respeito das limitações constitucionais na perspectiva intergeracional e busca justificar o motivo pelo qual as gerações passadas têm o direito de criar normas para as gerações futuras, ou seja, ele apresenta argumentos favoráveis ao modelo do pré-compromisso constitucional.

A teoria do pré-compromisso é uma tentativa de resposta ao que Elster (1989, p. 159) definiu como o paradoxo da democracia (constitucional), a saber, "cada geração deseja ser livre para obrigar seus sucessores, mas não quer ser obrigada pelos seus predecessores”. No entendimento de Holmes, as normas herdadas do passado, ou o pré-compromisso constitucional, não devem ser entendidas como um fardo, haja vista possuírem também um aspecto positivo e constitutivo. A posição de Holmes (1988b, p. 222-3) é sustentada a partir de três principais argumentos.

Primeiramente, ele defende que o pré-compromisso constitucional permite a "divisão intergeracional do trabalho", proporcionando vantagens tais como a organização da vida política para as futuras gerações, ao criar instituições e procedimentos que nortearão o exercício do poder político em sociedade. Sendo assim, uma estrutura política herdada pode fortalecer e estabilizar a democracia ao liberar a geração presente de ter que se ocupar constantemente com a fundação de uma estrutura básica para a vida política. Neste sentido, haveria uma dependência da soberania popular presente em relação ao pré-compromisso do passado. Para Holmes, a crítica formulada por Jefferson e Paine contra as obrigações (constituições) impostas a uma geração pela predecessora, a qual ele considera "intoxicada pela garantia do progresso", falha justamente por não entender a importância do papel organizacional desempenhado pela constituição, que pode desincumbir as gerações futuras. Assim, a herança do passado não é vista como um fardo, mas como algo que desobriga da tarefa de se dedicar constantemente a uma nova fundação. ${ }^{7}$

Um segundo argumento é apresentado por Holmes em face da dessemelhança apontada por Elster entre a ação política dos fundadores (poder constituinte) e a ação política das gerações subsequentes (poder constituído). ${ }^{8}$ Holmes tende a diminuir a diferença entre

\footnotetext{
${ }^{7}$ Holmes se refere aqui à afirmação de Jefferson (1977, p. 445) de que "a terra pertence em usufruto aos vivos: os mortos não têm poderes ou direitos sobre ela", isto é, nenhuma geração tem direito de criar normas para a geração futura. Do mesmo modo, Paine $(2009$, p. 204) sustentou que "os direitos do homem são os direitos de todas as gerações de homens e não podem ser monopolizados por nenhuma.”. Ou seja, não é permitido ao povo de uma determinada época determinar quais serão os direitos e qual será a forma de governo de seus sucessores.

${ }^{8}$ Essa distinção apontada por Elster é identificada também por outra teoria que busca justificar a legitimidade das restrições constitucionais à soberania popular, a saber, a teoria da democracia dualista de Bruce Ackerman (1991). Segundo este autor, o processo político pode ser compreendido de dois modos distintos: a partir da política constitucional - que consiste nos momentos raros em que o povo é chamado a decidir questões políticas consideradas fundamentais, como ocorreu na elaboração das emendas constitucionais após a guerra civil norteamericana ou no New Deal, e a partir da política normal - aquela feita corriqueiramente pelo Congresso.

Revista da Faculdade de Direito - UFPR, Curitiba, vol. 59, n. 2, p. 143-173, 2014.
} 
essas duas formas de exercício do poder político invocando certo ethos intergeracional. Segundo ele, nem mesmo o poder constituinte está completamente isento de influências passadas, mas, ao contrário, sempre reconhece e faz uso de conhecimentos e experiências dos antecessores. Ele usa como exemplo os framers da constituição norte-americana, que se apoiaram nas teorias políticas de autores como Harrington, Locke e Montesquieu (entre outros), na experiência da prática política inglesa e também nas constituições estaduais préexistentes. Ou seja, aqueles que fundam uma constituição hoje fazem isso com base na influência do passado e, futuramente, exercerão influência sobre as novas gerações. Ademais, apesar de a constituição figurar como um pré-compromisso estabelecido no passado, sempre há espaço para inovações introduzidas por meio de reformas.

O terceiro argumento sustenta que o pré-compromisso constitucional tem um aspecto predominantemente constitutivo na medida em que preserva algumas possibilidades que poderiam estar indisponíveis para as gerações futuras caso não houvesse nenhuma restrição. O exemplo invocado por Holmes (1988b, p. 226) é a proibição da escravidão, em que "por meio de uma constituição, a geração $a$ pode ajudar a geração $c$ a proteger-se de ser vendida como escrava pela geração $b$ ”. Sendo assim, para assegurar o poder de decisão das maiorias futuras, é preciso limitar constitucionalmente o poder de cada maioria. Holmes (1988b, p. 227) ${ }^{9}$ equipara as regras constitucionais àquelas da gramática ou de um jogo: "[e]nquanto regras regulativas (por exemplo, 'proibido fumar') governam atividades preexistentes, regras constitutivas (por exemplo, 'bispos se movem na diagonal') tornam uma prática possível pela primeira vez". Assim, o elemento essencial aqui é que a rigidez constitucional pode criar espaço para a flexibilidade. Isso ocorre, por exemplo, quando essas regras estabelecem a estrutura de governo, garantem a participação popular no processo político, regulam o modo como os poderes são empregados, asseguram a igualdade de tratamento. Desse modo, no entendimento de Holmes, as normas constitucionais possibilitam (ao invés de incapacitar) a democracia. Por essa razão, o autor considera insatisfatória a identificação do constitucionalismo unicamente com a limitação do poder. Nesse sentido, o modelo de précompromisso de Ulisses não pode ser tomado como análogo ao ato de criar e ratificar constituições, exatamente por centrar-se nos aspectos restritivos e não abarcar o aspecto criativo e organizacional inerente às constituições.

Como resultado, tem-se que, embora Holmes sustente que o constitucionalismo tem como uma de suas funções precípuas o estabelecimento de limites à democracia a fim de

\footnotetext{
${ }^{9}$ Os grifos constam do texto original.

Revista da Faculdade de Direito - UFPR, Curitiba, vol. 59, n. 2, p. 143-173, 2014.
} 
preservar os direitos fundamentais, esse não é seu único papel, haja vista que a própria constituição é compreendida como um mecanismo capaz de fortalecer a democracia na medida em que cria as instituições nas quais se realizarão as práticas democráticas. Por essa razão, pode-se dizer que ele nega a existência da tensão entre constituição e democracia. ${ }^{10}$

\section{$1.2 \mathrm{POVO}$}

Quando se trata de tentar definir a concepção de povo à qual se reporta o constitucionalismo e a teoria do pré-compromisso constitucional, observa-se, na contemporaneidade, certa continuidade com o constitucionalismo moderno, sobretudo com relação à teoria de Madison. Por um lado, identifica-se uma concepção diacrônica de povo, isto é, o povo é entendido de forma abstrata, compreendendo a geração presente, a passada e as futuras, ${ }^{11}$ no sentido de que as proteções estabelecidas pela constituição têm o intuito de velar pelo legado dos mortos e pelo direito dos vivos e também daqueles que ainda irão nascer; ou seja, o povo é pensado a partir das várias gerações. Por outro lado, predomina uma concepção pessimista da natureza humana, que joga com a dicotomia lucidez/embriaguês, força e fraqueza da vontade, de modo que a lucidez e a vontade racional se encontram sempre presentes naqueles que erigem as restrições constitucionais e abandonam os que almejam mudanças. Ou seja, uma racionalidade rara deve regular a vida daqueles que, na maior parte do tempo, não são racionais.

A teoria do pré-compromisso constitucional recorre a metáforas como a de Ulisses ou a do caso da embriaguês, nas quais um agente $A$ (indivíduo ou povo) em pleno uso de suas faculdades racionais se compromete a si mesmo em determinado tempo (T1) prevendo que em tempo posterior (T2) estará sob a influência de paixões e seu julgamento será afetado. Sendo assim, o agente $A$ confia ao agente $B$ o poder de tomar decisões em $T 2$, as quais deverão seguir rigorosamente as instruções previstas no pré-compromisso estipulado pelo próprio agente $A$ em $T 1$.

Em ambos os casos, o pré-compromisso se dirige àqueles passíveis de irracionalidade. O modelo de Ulisses, reapresentado por Elster, trata de um agente autônomo que se autorrestringe justamente para não perder sua autonomia no momento de perda de sua capacidade racional. No caso da embriaguês, apresentado por Hayek (2011, p. 266), quando as restrições constitucionais são invocadas para atender um apelo do povo bêbado ao povo

\footnotetext{
${ }^{10}$ Nesse sentido também é o posicionamento de Dworkin - cf. DWORKIN, 2006.

${ }^{11}$ A respeito do conceito de povo em sentido diacrônico e sincrônico ver PINZANI, 2013, p. 135-68.

Revista da Faculdade de Direito - UFPR, Curitiba, vol. 59, n. 2, p. 143-173, 2014.
} 
sóbrio, o que se está sustentando é que "todos os homens, na busca de objetivos imediatos, são aptos - ou, em razão da limitação de seu intelecto, de fato limitado - a violar regras de conduta que eles não obstante desejariam ver geralmente observadas”. Por essa razão, a constituição deve funcionar como uma decisão de longo prazo que se impõe sobre o poder temporário das maiorias.

Isso revela uma profunda desconfiança da capacidade do povo em tomar decisões corretas, haja vista que a proposta constitucionalista $T 2$ parece ocorrer no tempo padrão dos cidadãos nas sociedades contemporâneas. Nesse sentido, Holmes (1988b, p. 231) reconhece que "não faz sentido falar sobre governo popular além de algum tipo de estrutura legal que possibilite ao eleitorado ter uma vontade coerente". Essa estrutura legal deve necessariamente estabelecer restrições, pois “sem atar suas próprias mãos, o povo não terá mãos".

Holmes (1988b, p. 236-7), entretanto, não pensa que a analogia da embriaguês trazida por Hayek seja completamente adequada porque, em seu entendimento, "mesmo uma geração futura perfeitamente racional, lúcida e virtuosa poderia beneficiar-se com procedimentos pré-estabelecidos para resolver conflitos". Seria mais apropriado pensar o précompromisso em termos de autopaternalismo, no qual as "[p]essoas podem voluntariamente renunciar sua capacidade de escolha (em algumas matérias) a fim de realizar sua vontade (em outras matérias). A autolimitação coletiva pode ser um instrumento do autogoverno coletivo". Exemplos cotidianos podem ser invocados para demonstrar de que forma pré-compromissos individuais são feitos na forma de autopaternalismo, como quando se coloca o despertador longe da cama para se obrigar a levantar para desligá-lo e assim evitar que se volte a dormir, ou quando se está fazendo dieta e se evita ter em casa alimentos calóricos. Embora considere o autopaternalismo uma categoria útil para esclarecer a função democrática das restrições constitucionais, Holmes sustenta que o autopaternalismo constitucional difere do autopaternalismo individual em três aspectos.

Em primeiro lugar, o autopaternalismo constitucional não deve ser pensado em termos de autoincapacitação. Segundo Holmes, no caso do autopaternalismo individual a autorrestrição implica inevitavelmente a limitação da capacidade preexistente de escolha, até mesmo se o subsequente âmbito de escolhas for aumentado em decorrência da limitação inicial (no caso do despertador longe da cama, por exemplo, o agente não poderá mais optar por desligar o alarme sem sair da cama, ainda que aumente suas chances de chegar no horário em seu trabalho). O mesmo não ocorreria com a autolimitação constitucional, uma vez que as constituições possuem mecanismos que fomentam a discussão, estabelecem prazos para a tomada de decisões e acabam por melhorar a qualidade das escolhas. Sendo assim, "[q]uando 
uma assembléia constituinte estabelece um procedimento de decisão, ao invés de restringir a vontade preexistente, ela de fato cria uma estrutura na qual uma nação pode, pela primeira vez, ter uma vontade" (HOLMES, 1988b, p. 238).

Em segundo lugar, em questões individuais, o autopaternalismo permite a substituição da força de vontade pela auto-obrigação, como no caso da pessoa que quer emagrecer e não tem chocolates em casa. No caso de sociedades, essa substituição não se estabelece nos mesmos termos, pois a exigência de manutenção de uma "virtude coletiva inabalável" é algo que "sobrecarregaria a consciência individual, forçaria a padronização do caráter dos cidadãos e privaria a sociedade de uma variedade extrapolítica de selves" (HOLMES, 1988b, p. 238). ${ }^{12}$ Por essa razão, os dispositivos constitucionais, como, por exemplo, os freios e contrapesos, são concebidos como superiores à virtude pessoal dos cidadãos e à força de caráter.

Em terceiro lugar, o autopaternalismo constitucional se afasta do individual porque este possui um único propósito, a saber, a autoincapacitação, enquanto aquele tem muitos e "é intencionalmente delineado para ser útil a propósitos futuros ainda desconhecidos" (HOLMES, 1988b, p. 238).

Holmes afasta o argumento da irracionalidade do povo enquanto agente político, mas sua defesa do pré-compromisso como autopaternalismo ainda guarda certa desconfiança da capacidade de autonomia coletiva, uma vez que, embora o autopaternalismo não se apóie na irracionalidade do agente, ele parece se basear em uma espécie de fraqueza da vontade, que também compromete a ideia de autonomia.

\subsection{DEMOCRACIA}

O conceito de democracia adotado pelo constitucionalismo é delineado por Holmes a partir de dois aspectos complementares, a saber: a retirada de alguns temas do debate político (gag rules) e a autovinculação (self-binding). O primeiro aspecto é defendido em Gag rules or politics of omission; o segundo em Precommitment and the paradox of democracy, ambos de 1988.

Em Gag rules or politics of omission Holmes propõe pensar a democracia do ponto de vista inverso ao qual ela é sempre pensada - a democracia é geralmente associada àquilo que Berlin (2002) chamou de liberdade positiva, e as restrições à inserção de temas no debate político normalmente são consideradas como uma diminuição do caráter democrático de uma

12 Itálico acrescentado na palavra não traduzida do original.

Revista da Faculdade de Direito - UFPR, Curitiba, vol. 59, n. 2, p. 143-173, 2014. 
sociedade. Holmes, ao contrário, parte dos benefícios que podem advir para a vida pública se excluídas certas questões, sobretudo aquelas extremamente controvertidas, da discussão política. Nesse sentido, seria o conceito negativo de liberdade, ou seja, a ausência de interferência em alguns campos, que daria o tom para a democracia.

Apoiando-se na tese de Rawls (1985, p. 223-51), Holmes sustenta que a exclusão de alguns temas da agenda política se justificaria porque, para se estabelecer uma concepção de justiça que possa ser aceita por todos dos membros de uma sociedade diversificada, é preciso abstrair questões que suscitam um desacordo radical. Sendo assim, questões afetas à religião, por exemplo, devem ficar fora da pauta, haja vista a dificuldade de se chegar a um acordo sobre elas. Do mesmo modo, ele menciona o aborto, tema extremamente controvertido para o qual argumentos (pró-vida e pró-escolha) podem ser suficientemente fortes para sustentar um desacordo genuíno entre os opositores. A colocação desta espécie de tema na pauta, no entendimento de Holmes (1988a, p. 24), apenas promoveria o retardamento da discussão de outros temas para os quais um acordo seria possível. Nesse sentido, "direitos privados contribuem vitalmente para o governo democrático, expurgando disputas insolúveis da esfera pública”. A função desses direitos não é apenas proteger o espaço privado dos indivíduos, mas liberar o espaço público.

Por essa razão, Holmes (HOLMES, 1988a, p. 24-5) conclui que o "autoamordaçamento é então uma forma de autocontrole, não de autoestrangulamento". A omissão de alguns temas do debate pode ser útil tanto para postergar a discussão a respeito desses temas para um momento em que a sociedade esteja mais preparada para isso ou, ainda, para deslocar a discussão de uma instituição para outra (por exemplo, do legislativo para o judiciário ou vice-versa). Portanto, a democracia é definida mais pela "remoção de certos itens da agenda democrática" do que pela inclusão.

Em Precommitment and the paradox of democracy, Holmes ressalta que o conceito de democracia em sociedades que almejam uma constituição para proteger seus direitos fundamentais é efetivamente um conceito paradoxal. Aqui a palavra paradoxo parece ser utilizada no sentido de termos distintos, mas complementares e não no sentido de contradição ou de absurdidade. Caso contrário, o autor não poderia sustentar, como sustenta, que não há tensão entre o constitucionalismo e a democracia. ${ }^{13}$ A principal característica é então que, para que a democracia exista, a própria ação democrática precisa ser limitada. A democracia, diz Holmes (1988b, p. 231), "nunca é simplesmente o governo do povo, mas sempre o governo

${ }^{13}$ Cf. HOLMES, 1988b, p. 197-8 e 226.

Revista da Faculdade de Direito - UFPR, Curitiba, vol. 59, n. 2, p. 143-173, 2014. 
do povo dentro de certos canais predeterminados, de acordo com certos procedimentos préestabelecidos (...)".

A necessidade de imposição de limites está relacionada à concepção de indivíduo e de povo acima apresentada, segundo a qual o povo carece de uma virtude inabalável ou mesmo de fibra moral para não causar a si mesmo ou às gerações futuras um mal irreparável ou de difícil reparação, como, por exemplo, a autoescravidão que, aliás, seria extremamente contraditória na medida em que por meio de um ato voluntário um indivíduo (ou povo) abdicaria do direito de voluntariamente concordar ou discordar de algo.

Desse modo, "para preservar a voluntariedade, a própria voluntariedade deve ser restringida" (HOLMES, 1988b, p. 239). Holmes sugere que essa seria uma possível resposta ao paradoxo da democracia. O ponto central do conceito de democracia constitucional é que a constituição e as restrições impostas à democracia servem para fortalecer a própria democracia. Não há uma tensão entre os conceitos, mas um paradoxo na medida em que a democracia se fortalece quando é restringida pela retirada de alguns temas da pauta de discussão. A constituição, por sua vez, assume um papel positivo na criação de regras que permitem o debate e o exercício da participação política.

O que se pode chamar de leitura constitucionalista da democracia, nos termos daquela feita por Holmes, comunga de muitas das preocupações de Madison com relação ao controle do poder político. Assim como ele, os autores que sustentam esse argumento, embora atribuam aos cidadãos faculdades morais que os capacitam ao compartilhamento dos mais elevados princípios políticos de uma determinada sociedade, fiam-se mais nas instituições políticas criadas pela constituição do que no povo para efetuar o controle do poder político, principalmente no poder judiciário que, por meio da corte constitucional, é a instituição que assume maior relevância nestas teorias. Essa relevância fica ainda mais evidente quando se trata de assegurar direitos e liberdades fundamentais, os quais são colocados como limites ao exercício da soberania popular e cujos mecanismos de proteção são essencialmente jurídicos, quais sejam, sua interpretação e ponderação pelo poder judiciário. Compreendidos desse modo, não obstante o argumento do pré-compromisso constitucional, os direitos estão fora e não dentro da política. A constituição, logo, passa a ser compreendida como uma lei, com status superior ao das demais, cuja "interpretação própria e peculiar" cabe às cortes, como diria Hamilton (HAMILTON; JAY; MADISON, 1987, p. 439), e o aspecto político deste documento passa a ser secundário.

Se a discussão política se limita à interpretação constitucional, ou seja, a saber se uma determinada proposta ou desacordo sobre questões políticas é ou não compatível com a Revista da Faculdade de Direito - UFPR, Curitiba, vol. 59, n. 2, p. 143-173, 2014. 
proteção constitucional conferida aos direitos fundamentais, os únicos que têm a possibilidade de participar da formação de uma vontade coerente são os intérpretes da constituição que, na maioria das democracias ocidentais, são os juízes das cortes constitucionais. Surge então, como um sintoma da colocação da proteção dos direitos fundamentais acima das práticas democráticas, o problema que vem sendo chamado de judicialização da política, ${ }^{14}$ com a filosofia constitucional e do direito centrada mais nos problemas de interpretação e argumentação do que no processo de autodeterminação coletiva. ${ }^{15}$

Ao final, uma vez que os direitos fundamentais assumem um lugar central na arena política, a conciliação sugerida por Holmes parece não ser alcançada. ${ }^{16}$ Isso leva a discussão para o outro extremo, no qual surgem teorias que ressaltam o papel central da constituição na proteção e criação de meios para a realização da soberania popular.

\section{A CONSTITUIÇÃO COMO BALUARTE DA SOBERANIA POPULAR}

Um dos principais exemplos de teorias que buscam lançar luz sobre o papel da constituição na salvaguarda da soberania popular e da autonomia coletiva é a teoria de Jeremy Waldron. ${ }^{17} \mathrm{O}$ constitucionalista neozelandês diagnostica a centralidade dos direitos fundamentais na Filosofia Política e do Direito e propõe um deslocamento da atenção para as teorias da democracia e da autoridade. Segundo ele, a Filosofia Política tem duas tarefas precípuas, a saber, teorizar a respeito da justiça (direitos e bem comum) e teorizar sobre a política (teorias da autoridade e teorias da democracia). Desde que Rawls publicou $A$ theory of justice, em 1971, Waldron (1999a) considera que filósofos da política e do direito estão mais interessados em contribuir para o debate acerca de questões relacionadas às teorias da justiça do que em enfrentar o significado dos desacordos sobre justiça. Sua obra, entretanto, pretende apresentar uma contribuição para as teorias da autoridade e para as teorias da democracia, teorizando sobre os meios pelos quais as comunidades agem quando seus membros

${ }^{14}$ A respeito da supremacia judicial e judicialização da política ver: BELLAMY, 1996, p. 436-56; 1997, p. 595618; 2007. CITTADINO, 2002. KOZICKI; BARBOZA, 2012. KRAMER, 2004. MOREIRA, 2012. NOBRE; RODRIGUES, 2011. TUSHNET, 1999. WALDRON, 1993, p. 18-51; 1998, p. 271-99; 1999a; 2006; 2009.

${ }^{15}$ Esse é um dos principais argumentos levantados por Jeremy Waldron contra o constitucionalismo, como se verá a seguir.

${ }^{16}$ Além de Holmes, outros autores sustentam ser possível superar a tensão entre constituição e democracia. A partir de um viés substancialista, pode ser mencionado Ronald Dworkin (2006). A partir da defesa da teoria procedimentalista da democracia, John Hart Ely também tem essa pretensão. Cf. ELY, 1997; Para críticas ao modelo substancialista e procedimentalista ver: BELLAMY, 2007; WALDRON, 1999a.

17 Outras teorias, além da desenvolvida por Jeremy Waldron, buscam deslocar a discussão dos direitos fundamentais (e do papel do judiciário na interpretação desses direitos) para a política. Assim, podem também ser mencionadas como referências as teorias de Mark Tushnet (1999), Larry Kramer (2004) e Richard Bellamy (1996; 1997; 2007). No contexto brasileiro, Gilberto Bercovici $(2003 ; 2004 ; 2008)$ e Luiz Moreira $(2007 ; 2012)$ têm elaborado críticas semelhantes àquelas formuladas pelos autores acima mencionados.

Revista da Faculdade de Direito - UFPR, Curitiba, vol. 59, n. 2, p. 143-173, 2014. 
discordam.

Reportando-se a uma conclusão de Mangabeira Unger (1996) segundo a qual há, na Teoria e na Filosofia do Direito, um mal-estar com a democracia que resulta na marginalização da legislação, Waldron, tanto em Law and disagreement quanto em The dignity of legislation e em outros textos, busca desfazer esse mal-estar.

Tendo como ponto de partida aquilo que Rawls (1999, p. 109) considerou como as "circunstâncias da justiça", a saber, que em condições normais sob as quais a cooperação humana é possível e necessária, as regras sociais e legais criam certos direitos para estabilizar as relações humanas, o constitucionalismo contemporâneo sustenta que as constituições devem abrigar três diferentes conjuntos de direitos, relacionados à justiça (liberdade individual de pensamento, consciência e ação, propriedade, trabalho, família, entre outros), à consistência (devido processo legal e igualdade perante a lei) e à equidade (aqueles associados ao funcionamento da democracia, tais como a liberdade de expressão e associação, funcionamento do sistema eleitoral etc.). ${ }^{18}$

Embora esses direitos sejam relacionados e suportem-se mutuamente, pode haver tensão entre eles no momento de sua aplicação social, uma vez que sua natureza e significado podem ser objeto de divergências (por exemplo: direito à vida versus aborto; direito de propriedade versus bem-estar social; liberdade de expressão versus privacidade). Desse modo, embora os direitos sejam necessários em razão das "circunstâncias da justiça", eles devem ser identificados e interpretados no que Waldron (1999a, p. 101-2) chamou de "circunstâncias da política", ou seja, em circunstâncias nas quais é preciso chegar a um acordo coletivo e coercitivo sobre o caráter dos direitos, haja vista a existência de opiniões e interesses divergentes.

Considerando que as pessoas divergem sobre a interpretação dos direitos e, também levando em conta que essas divergências muitas vezes espelham desacordos não apenas sobre direitos, mas principalmente a respeito da política, de sua estrutura e de suas metas (debates entre liberais e conservadores, por exemplo), o desacordo a respeito dos direitos e também da política mostra que a relação entre constituição e democracia continua a ser conflituosa, assim como reconhecido pelo constitucionalismo moderno. A proposta de Waldron para avaliar essa relação é, contudo, bastante distinta daquela do constitucionalismo segundo apresentado a partir da teoria de Holmes. Isso pode ser constatado a partir da forma como o autor define os mesmos conceitos analisados anteriormente segundo a leitura constitucionalista da

${ }^{18}$ Essa apresentação e distinção dos conjuntos de direitos é tomada de Richard Bellamy - cf. BELLAMY, 2007, p. 18-9. 
democracia constitucional, quais sejam: constituição, povo e democracia.

\subsection{CONSTITUIÇÃO}

De acordo com Waldron o conceito de constituição não deve ser definido meramente pelas restrições que esse documento coloca à política e ao governo. É exatamente esse aspecto restritivo atribuído à constituição pelo constitucionalismo que é objeto de contestação pelo autor. Ele considera que existem alguns aspectos das constituições escritas que devem ser ressaltados em detrimento de outros. Nesse sentido, uma das desvantagens das constituições escritas é que elas reforçam, entre os juristas, a teoria interpretativa e encorajam um formalismo textual rígido. Por outro lado, as constituições escritas desempenham uma importante função na política, qual seja, a de servir de base para as deliberações e, sendo assim, seu papel é mais de fortalecer a política e o governo do que de restringi-los. (WALDRON, 2009).

O constitucionalismo, segundo Waldron (2009, p. 271), define as constituições principalmente a partir de três verbos: controlar (control) restringir (restraint) e limitar (limit). A reavaliação do conceito de constituição passa pela diferenciação desses termos. $\mathrm{O}$ sentido atribuído ao termo controle é positivo, e difere da conotação restritiva com a qual comumente ele é associado. O controle deve ser entendido no sentido de direção e não de repressão ou restrição. "Se eu controlo um veículo, eu determino não somente aonde ele não vai, mas também aonde ele vai. E se o governo é controlado, deve-se pensar que a questão importante é quem está no banco do motorista".

$\mathrm{Na}$ proposta waldroniana este lugar deve ser ocupado pelo povo, ou por seus representantes, que devem decidir quais metas e diretrizes políticas devem estar contidas na constituição para que possam ser dirigidas ao fim escolhido. Assim, "[s]e o povo quer que seu governo atenue a pobreza, por exemplo, é tarefa da constituição proporcionar instituições que possam ser controladas por este desejo" (WALDRON, 2009, p. 271).

Já o termo restrição, ao contrário do termo controle, efetivamente guarda um sentido negativo. Trata-se de impedir o governo, por meio de proibições inseridas no texto constitucional, de adotar determinadas atitudes definidas como abuso, tais como a prática da tortura ou a interferência em questões religiosas. Essas proibições, herança do constitucionalismo moderno, assumem a forma de direitos. Contudo, o autor identifica no constitucionalismo contemporâneo outra função atribuída à noção de restrição imposta pela constituição, que é a de "limitar afirmativamente o tipo de coisa que os governos podem 
fazer" (WALDRON, 2009, p. 272). O significado atribuído ao termo limitação é similar ao de restrição, ou seja, não está vinculado apenas à ideia de evitar abusos do governo sobre direitos e interesses particulares, mas de dizer o que é ou não função do governo. A crítica de Waldron aqui não recai sobre o que poderia ser estabelecido na constituição como aquilo que é função do governo, pois isso se coadunaria com o papel de direção que ele considera fundamental para o fortalecimento das metas estabelecidas politicamente; papel, aliás, bastante comum em constituições que possuem normas que visam sobretudo a implementação de direitos fundamentais de cunho social. Sua preocupação recai sobre a possibilidade de que esse aspecto restritivo-limitativo a respeito do que o governo deve fazer seja utilizado para impedir a implementação de decisões democráticas. ${ }^{19}$

Direção (controle) e restrição são aspectos que podem levar a compreensões distintas do papel desempenhado pela constituição. A crítica que Waldron direciona ao constitucionalismo é de, ao ressaltar o aspecto de restrição do texto constitucional, diminuir seu papel no fortalecimento da democracia. Como visto acima, esse aspecto foi também apontado por Holmes. Contudo, a argumentação de Holmes vai ao sentido oposto àquela de Waldron. Enquanto Holmes pensa que a constituição fortalece a democracia justamente porque restringe e limita o debate político, Waldron defende que a constituição pode fortalecer a democracia desde que não seja colocada como algo que restringe e limita a discussão e deliberação sobre os temas em desacordo.

Segundo Waldron (1998), quando Holmes ressalta o aspecto criativo e organizacional da constituição, ele está se referindo aos procedimentos políticos e, nesse aspecto, ele equipara as regras constitutivas (as regras procedimentais que criam as condições das práticas democráticas) ao pré-compromisso, uma vez que elas são retiradas da conversação política justamente para que possam nortear o debate e as decisões políticas. Para Waldron (1998, p. 290), as regras procedimentais não podem ser consideradas meramente como uma limitação ou restrição ao debate uma vez que "elas tornam a participação possível por meio do estabelecimento de uma matriz de interação na qual contribuições particulares podem tomar o seu lugar e ser 'registradas', por assim dizer”. Assim sendo, embora ambos sustentem a importância da constituição na criação das instituições e regras procedimentais que nortearão a prática democrática, Waldron discorda de Holmes quanto ao aspecto restritivo dessas regras.

Desse modo, a constituição pode contribuir para o fortalecimento da democracia na medida em que ela estabelece "instituições que permitem ao povo cooperar e coordenar para

${ }^{19}$ Aqui Waldron (2009, p. 272) se preocupa com uma possível associação ou uso do ideal constitucionalista por ideólogos do Estado mínimo.

Revista da Faculdade de Direito - UFPR, Curitiba, vol. 59, n. 2, p. 143-173, 2014. 
perseguir projetos que ele não alcançaria sozinho" (WALDRON, 2009, p. 273). Essas instituições se referem a cada um dos poderes (executivo, legislativo e judiciário), assim como às agências administrativas ligadas a eles, as quais possibilitam e canalizam as demandas cotidianas dos cidadãos. Ao lado das instituições, as constituições também estabelecem os procedimentos por meio dos quais a política se realiza. Uma política constitucionalizada, diz Waldron,

\begin{abstract}
é uma política articulada que deliberadamente e deliberativamente, de estágio a estágio e de fórum a fórum, leva a sério a integridade de cada parte de [dizer] o processo de elaboração da lei ou de outro processo de decisão política. Eu tenho em mente processos como a legislação bicameral, o requerimento do consentimento executivo, a relação articulada entre a legislatura, de um lado, e as cortes e agentes do executivo que administram, interpretam e aplicam as leis (WALDRON, 2009, p. 273-4).
\end{abstract}

A proposta do autor é que tais mecanismos sejam vistos como um meio de estruturar a deliberação e não meramente como um modo de frear e diluir o poder político. Nesse sentido, "arranjos bicamerais podem ser vistos como modos de capacitar diferentes vozes na sociedade; e a separação dos poderes pode ser vista como um modo de levar a sério a integridade do que vem à existência como resultado de um genuíno exercício legislativo" (WALDRON, 2009, p. 274). Waldron não chega a propor novos arranjos institucionais, mas sim uma readaptação dos arranjos já existentes, a fim de que seja ressaltada

\begin{abstract}
a importância do modo em que a constituição fornece abrigo para a atividade política de uma sociedade, estabelecendo um meio-termo de equipamento e formalidade de modo que a deliberação pública se torne um empreendimento estruturado, permitindo que as visões de uma pessoa sejam trazidas articuladamente em relação às visões de outras e facilitando a formação de opiniões bem pensadas, responsáveis e politicamente efetivas. Isso não é primariamente uma questão de restrição; é uma questão do que uma constituição afirmativamente torna possível a partir de algo que de outra maneira seria a política solta e cambaleante das ruas. (WALDRON, 2009, p. 274, grifo do autor).
\end{abstract}

A constituição pode então ser definida como um mecanismo que confere poder ao "povo ordinário em uma democracia e permite a ele controlar as fontes do direito e aproveitar o aparelho do governo para suas aspirações" (WALDRON, 2009, p. 279). Desse modo, o que entra em conflito com o ideal democrático não é a constituição propriamente dita, mas sim o modo como ela é definida. Se compreendida como uma restrição, ela pode ser inconciliável com a democracia. Se compreendida como algo que fortalece ou cria condições, então ela de fato possibilita a democracia. O problema apontado por Waldron é a ênfase dada pelo constitucionalismo no aspecto restritivo da constituição. De acordo com essa perspectiva, não haveria necessariamente um conflito entre constituição e democracia, mas sim entre o constitucionalismo e a democracia.

Revista da Faculdade de Direito - UFPR, Curitiba, vol. 59, n. 2, p. 143-173, 2014. 


\subsection{POVO}

Se o conceito de povo atribuído ao constitucionalismo é definido em termos madisonianos, ou seja, parte de uma concepção pessimista da natureza humana e é pensado a partir de uma perspectiva diacrônica na medida em que funda uma constituição com validade intergeracional justamente para impedir que a atuação dos indivíduos movidos por paixões ou interesses viole direitos fundamentais, o conceito de povo da teoria de Waldron pode ser equiparado àquele de Jefferson, isto é, à concepção sincrônica, segundo a qual o povo é definido pelos indivíduos concretos que compõem em um dado momento histórico o corpo de cidadãos, sem considerar a necessidade de preservação do legado das gerações passadas ou em estabelecer algo para as gerações futuras. Segundo essa perspectiva, os indivíduos são compreendidos como agentes autônomos e responsáveis, capazes de pensamento moral e, por consequência, aptos a participarem do debate e da tomada de decisões políticas. Para Waldron (1999b, p. 232), assim como para Jefferson, a participação política é para os cidadãos "o direito dos direitos". O povo poderia ser pensado sincronicamente porque todos os direitos, valores e princípios que estão sujeitos a desacordo devem ser submetidos ao debate político realizado entre os indivíduos da geração atual. Não há uma reserva de temas e de direitos como na proposta constitucionalista.

A análise da crítica de Waldron ao pré-compromisso constitucional oferece uma chave de leitura para identificar o conceito de povo contido em sua teoria. A crítica é formulada a partir do conceito de autonomia dos cidadãos enquanto sujeitos de direitos e também a partir da constatação da submissão das sociedades contemporâneas às "circunstâncias da política". Essa crítica, formulada inicialmente em Precommitment and disagreement (WALDRON, 1998, p. 271-99), é reproduzida posteriormente como um dos capítulos de Law and disagreement (WALDRON, 1999a) e se dirige, sobretudo, à assunção do constitucionalismo segundo a qual "o pré-compromisso é uma forma de autogoverno - que é governo não somente do povo, mas pelo povo - ou que preserva o caráter democrático e de autogoverno de um regime" (WALDRON, 1998, p. 279). ${ }^{20}$

Ao se debruçar sobre os argumentos que sustentam as teorias do pré-compromisso constitucional, notadamente sobre o argumento da autolimitação, Waldron observa que quando um agente limita a si mesmo isso implica, ao menos temporariamente, depositar sua vontade em uma estrutura externa, como na tripulação no caso de Ulisses, ou no amigo, no caso do bêbado. Retomando de Elster o estudo da relação entre pré-compromisso e 
mecanismos causais (como exemplo de um mecanismo causal, Waldron imagina algo como um dispositivo instalado em carros com a capacidade de detectar a quantidade de álcool que o motorista possui no sangue e, se for identificado que essa quantidade é superior à permitida por lei, o mecanismo automaticamente impede que o motor do carro seja ligado), o autor constata que o pré-compromisso não funciona mecanicamente. $\mathrm{O}$ fato de alguém entregar as chaves de seu carro a um amigo antes de beber, por exemplo, não funcionaria como um mecanismo causal, haja vista depender do julgamento do amigo. As restrições constitucionais, assim como o modelo do julgamento do amigo, não funcionam como um mecanismo causal, mas investem "o poder de decisão em alguma pessoa ou corpo de pessoas (uma corte) cujo trabalho é determinar como uma questão de julgamento se a conduta que é contemplada (diga-se, pela legislatura) em $T 2$ viola uma restrição escrita em T1" (WALDRON, 1998, p. 278, grifo do autor).

Segundo o autor, há vantagens e desvantagens no uso desse tipo de mecanismo. A vantagem do uso de um mecanismo não causal é que ele não opera de forma deontológica ou rígida, o que possibilita que em situações-limite como, por exemplo, quando uma pessoa que ingeriu mais bebida alcoólica do que o permitido por lei é a única que pode conduzir até um hospital alguém que está correndo risco de vida, há a possibilidade de o responsável pelo julgamento conforme as restrições iniciais, mediante a ponderação dos interesses e bens em questão, abrir uma exceção à regra. A desvantagem é que o agente externo pode decidir de modo distinto das intenções iniciais do agente que instituiu as regras (WALDRON, 1998).

Essa desvantagem é acentuada na proporção da abstração das regras contidas no précompromisso. Se as instruções dadas inicialmente são bastante precisas, a decisão do julgador externo se torna apenas um meio de cumprimento da vontade racional daquele que as instituiu e, desse modo, em tese, não haveria incompatibilidade entre a autonomia e pré-compromisso. Contudo, os problemas referentes ao julgamento externo devem ser enfrentados levando-se em consideração que os princípios e valores embutidos em uma constituição serão interpretados perante as circunstâncias da política, ou seja, em circunstâncias nas quais vigora o desacordo político não apenas a respeito de questões de direito, mas também a respeito de questões de justiça e de política. Sendo assim, nas sociedades hodiernas, dificilmente o requisito da precisão da instrução inicial estará presente para que o pré-compromisso constitucional possa ser conciliado com a autonomia. Nas palavras do autor:

O pré-compromisso não pode preservar a aura de autonomia (ou democracia no caso constitucional) a menos que a pessoa vinculada realmente seja o juiz do ponto e extensão de sua vinculação. (...) Então, similarmente, se seguimos a lógica do précompromisso no caso político, o povo é presumivelmente autoridade - não juízes em Revista da Faculdade de Direito - UFPR, Curitiba, vol. 59, n. 2, p. 143-173, 2014. 
sua própria causa, mas autoridades - sobre o que ele comprometeu a si mesmo. Se essa autoridade é desafiada, por exemplo, porque o povo é agora pensado estar no próprio estado (de pânico ou fúria etc.) que ele desejou se comprometer para combater, então tudo que podemos dizer é que a noção de pré-compromisso já não é útil em relação à controvérsia. Uma vez que se torna incerto ou controverso ao que o povo comprometeu a si mesmo, já não existe mais qualquer base na ideia de précompromisso para defender uma interpretação particular contra as objeções democráticas (WALDRON, 1998, p. 281, grifo do autor).

Surge aqui, então, a questão da autonomia dos sujeitos de direito e da capacidade do povo de fazer julgamentos a respeito de questões políticas. Segundo Waldron (1998, p. 281), a tradição democrática sempre partiu do pressuposto de que o povo "é capaz de governar a si mesmo por seu próprio julgamento". Esse é também o ponto de partida da teoria da democracia waldroniana. Em Law and disagreement, ao analisar a relação entre direitos e declarações de direitos, o autor constata que as declarações figuram como pré-compromissos que retiram do debate político os direitos fundamentais. Em seu entendimento, o entrincheiramento dos direitos em declarações pode ser considerado uma afronta à autonomia e à responsabilidade dos cidadãos, uma vez que "o povo tem o direito de participar em todos os aspectos do governo democrático de sua comunidade, um direito que está profundamente conectado aos valores da autonomia e da responsabilidade que são celebrados em nosso compromisso com outras liberdades básicas” (WALDRON, 1999a, p. 213).

O que está em questão aqui é a desigualdade de consideração destinada aos fundadores da constituição e aos cidadãos. Essa dessemelhança é apontada a partir da contraposição entre autoconfiança e desconfiança, de modo que aqueles que instituem as restrições constitucionais confiam em si mesmos como agindo em nome do interesse comum e desconfiam das futuras gerações considerando que serão movidas por paixões e interesses. A desconfiança para com os concidadãos, diz Waldron (1999a, p. 222), "não se encaixa particularmente bem com a aura de autonomia e responsabilidade que é veiculada pela substância dos direitos que estão sendo entrincheirados desse modo". Há, então, uma contradição dentro da própria concepção (liberal) de sujeito de direito, pois, por um lado, quando se trata de adquirir direitos, os indivíduos são tomados como merecedores de igual consideração e respeito justamente porque são considerados capazes de agir moral e racionalmente; por outro lado, no momento do exercício de seus direitos políticos os indivíduos são considerados pouco confiáveis, irresponsáveis e irracionais. Sendo assim,

se o desejo de entrincheiramento é motivado por uma visão predatória da natureza humana e do que as pessoas farão umas para as outras quando soltas na arena da política democrática, será difícil explicar como ou por que as pessoas são vistas como essencialmente portadoras de direitos. (WALDRON, 1999a, p. 222) 
Logo, também é contraditório tentar combinar, como faz o constitucionalismo, a proteção aos direitos e a desconfiança do povo na participação em decisões políticas nas quais há direitos em desacordo. Para que haja coerência, é preciso assumir que os indivíduos são tão confiáveis como portadores de responsabilidades políticas quanto o são como portadores de direitos. Waldron (1999a, p. 223) expressa essa confiança nos seguintes termos: "é precisamente porque eu vejo cada pessoa como um potencial agente moral, dotado de dignidade e autonomia, que estou disposto a confiar ao povo em massa o encargo do autogoverno".

É exatamente essa concepção dos indivíduos e, por conseguinte, do povo, como agentes autônomos e responsáveis, que serve de base para a recusa do pré-compromisso pautado no modelo de Ulisses ou do bêbado. Waldron considera que existe uma grande diferença entre o pré-compromisso individual, ao qual fazem menção as narrativas de Ulisses e do bêbado, e o pré-compromisso coletivo (propriamente o que seria o modelo de autolimitação por meio de uma constituição). Em uma sociedade, mesmo em momentos de lucidez há desacordos a respeito de como os direitos são concebidos, pesados e relacionados a outros valores. E, o que está presente não é uma embriaguez, mas sim incertezas genuínas e mudanças de opinião. Por essa razão, os desacordos sobre direitos devem ser considerados desacordos de boa fé ou razoáveis, isto é, desacordos oriundos da ausência de consenso entre posicionamentos que podem ser sustentados racionalmente. A questão do aborto é trazida como um exemplo, haja vista que tanto os grupos em defesa da vida do feto quanto aqueles que priorizam o direito de escolha da mulher não são movidos por paixões ou interesses unicamente privados, mas estão convictos de que sua posição é a mais justa para a sociedade. $^{21}$

Segundo o autor, a metáfora ideal seria a do caso teológico, no qual uma pessoa dividida entre crenças religiosas distintas opta por uma fé fundamentalista e entrega a chave de sua biblioteca pessoal, na qual existem livros sobre diversas crenças, a um amigo e pede que a chave jamais lhe seja devolvida. Algum tempo depois a pessoa quer voltar à sua biblioteca e solicita ao amigo a devolução da chave. Com base nesse exemplo, ele busca demonstrar que as opiniões sobre decisões relevantes mudam ao longo do tempo e devem estar disponíveis para serem reavaliadas pelo próprio agente que as instituiu. Por essa razão,

\footnotetext{
${ }^{21}$ Note-se aqui que Waldron invoca o mesmo exemplo de Holmes e, de certo modo, até o mesmo argumento segundo o qual o desacordo é profundo e genuíno. Contudo, as opiniões de ambos se dirigem a lados opostos. Holmes reconhece o desacordo e o invoca como motivo para tirar este tipo de tema do debate político. Waldron, ao contrário, considera que é justamente em razão da existência de desacordo que o tema deve estar disponível para o debate.
}

Revista da Faculdade de Direito - UFPR, Curitiba, vol. 59, n. 2, p. 143-173, 2014. 
ele sustenta que os temas divergentes devem ser submetidos ao debate atual (WALDRON, 1998).

Na esteira dessas conclusões, o autor reconhece que alguma espécie de précompromisso pode ser importante para constituir o povo. Em um sentido puramente formal, diz ele,

\begin{abstract}
uma comunidade política pode ser constituída por uma regra sobre a votação, mas tais regras procedimentais constituem uma realidade política significativa somente em relação ao contexto legal e social que condiciona o caráter do debate público. O governo pela maioria popular é uma coisa se os votos são tomados após longos períodos de argumentos trocados entre os cidadãos e seus representantes; é outra coisa se os votos são tomados sem qualquer interação deliberativa ou se a cultura política é tal que muitas pessoas temem manifestar sua oposição tão logo qualquer indício de consenso majoritário começa a emergir (WALDRON, 1998, p. 292).
\end{abstract}

Sendo assim, o único pré-compromisso compatível com a autonomia e responsabilidade dos cidadãos e, portanto, com a democracia, é aquele que leva em consideração o fato do desacordo político existente nas sociedades contemporâneas, deixando aberta a possibilidade de discussão sobre todos os temas que são objeto de desacordo. Nesse sentido, se é possível falar em um conceito de povo na teoria de Waldron, ele assume o caráter sincrônico, ou seja, é o conjunto dos indivíduos que formam no presente o corpo dos cidadãos e, para usar as palavras de Jefferson (1977), na condição de "vivos", estão autorizados a reavaliar a decisão e as instruções dos "mortos".

\title{
2.3 DEMOCRACIA
}

A compreensão da democracia, na perspectiva de Waldron, passa pela resposta dada a duas questões: 1) que direitos temos e 2) quem decide? A resposta para a primeira questão é dada por teorias dos direitos e, para a segunda, por teorias da autoridade. Dependendo das respostas dadas, pode haver compatibilidade ou descompasso entre essas teorias. De todo modo, o autor sustenta que qualquer resposta deve levar em consideração as circunstâncias da política, isto é, "a existência de desacordo e a necessidade de, apesar do desacordo, estabelecer uma estrutura comum" (WALDRON, 1999a, p. 212).

Waldron sustenta, em Law and disagreement, que a participação popular é um elemento decisivo na caracterização da democracia. Disso não é possível inferir, contudo, que o direito de participação conflita com outros direitos, ou ainda, que o direito de participação tem prioridade sobre os demais. Isso significa apenas que "a participação é um direito cujo exercício parece peculiarmente apropriado em situações em que portadores de direitos 
razoáveis discordam sobre que direitos eles têm" (WALDRON, 1999a, p. 212).

Como já visto anteriormente, Waldron sustenta que pode haver compatibilidade entre a ideia de direitos e democracia, haja vista a assunção de que a igual consideração que suporta os direitos é a mesma que deve suportar a autonomia e responsabilidade dos sujeitos de direitos. Do mesmo modo, ele considera que a relação entre direitos e democracia é uma via de mão dupla:

\begin{abstract}
Um teórico dos direitos não deveria retratar os membros ordinários de uma democracia majoritária como predadores egoístas e irresponsáveis. Mas igualmente um teórico da democracia não deveria assumir um puro interesse procedimentalista sobre a sorte dos direitos individuais sob um sistema de decisão majoritária, pois muitos desses direitos (até mesmo aqueles não implicados no ideal democrático) são baseados no respeito pela agência moral individual que a própria democracia envolve (WALDRON, 1999a, p. 282)
\end{abstract}

Assim, uma das principais questões para uma teoria da democracia é saber como proteger os direitos em um sistema de tomada de decisões democrático. Para levar a cabo esta análise, o autor considera dois conjuntos de direitos: 1) direitos constitutivos do processo democrático (direito de participar em termos iguais na resolução dos desacordos) e, 2) direitos que são condição de legitimidade ou de respeitabilidade moral da tomada de decisões democráticas (liberdade de expressão e de associação e algo pouco ou não procedimental relacionado ao igual respeito pelo julgamento dos outros membros). A legitimidade democrática está então associada à relação estabelecida entre esses conjuntos de direitos, sendo que os direitos do conjunto $a$ pressupõem os direitos do conjunto $b$. E eles devem ser considerados de modo que nem os direitos relacionados a valores morais (substância), nem aqueles relacionados aos procedimentos democráticos (forma) sejam excluídos do debate político, haja vista Waldron (1999a, p. 284-5) considerar que "[e]m um sentido amplo todos os direitos são associados com a democracia porque (...) todos os direitos requerem a mesma espécie de respeito para com os indivíduos que a democracia também requer".

Parece que para Waldron não há incompatibilidade entre direitos e democracia, mas, como já anunciado em sua compreensão de constituição e de povo, pode haver incompatibilidade entre uma declaração de direitos funcionando na forma de um précompromisso constitucional, ou seja, retirando os direitos nela salvaguardados do debate político, e democracia. Isso porque o entrincheiramento dos direitos em uma constituição modifica o modo de ser do processo democrático. Se o debate é norteado pela constituição, a qual diz o que pode e o que não pode ser discutido, então, discute-se se um determinado tema é ou não constitucional. Nesse caso, ao invés de se discutir a existência ou não de direitos, transforma-se a questão na discussão a respeito da constitucionalidade ou não do ponto em 
desacordo. Sendo assim, trata-se mais de uma questão de hermenêutica constitucional do que de enfrentamento e discussão de todos os princípios relacionados ao tema em debate.

Assim, o principal ponto em relação ao comprometimento da democracia pelo entrincheiramento de direitos é a retirada, do debate político, desses direitos em desacordo. Não se trata de saber quem deve interpretar a constituição, mas de quem decide quando há direitos em desacordo. Esse é o ponto no qual a questão dos direitos se cruza com a questão da autoridade. No entendimento de Waldron (1999a, p. 243), a política diz respeito tanto a princípios quanto a diretrizes políticas, pois, “[o] que acontece no processo político determina não somente o que nossas metas sociais são, mas também o conteúdo e a distribuição dos direitos individuais". Uma vez que as pessoas discordam sobre quais direitos possuem, a especificação dos direitos que devem ser protegidos pelo Direito deve ser feita por meio do processo político. Diante do desacordo, uma teoria da autoridade deve ser invocada e deve prevalecer sobre os critérios que são a fonte do desacordo original.

Em meio às teorias da autoridade tradicionalmente conhecidas na teoria política (monarquia, aristocracia, democracia) Waldron entende que na democracia é o povo quem deve decidir sobre os direitos que estão em discussão, devendo participar, em termos iguais, dessa decisão. A pergunta quem decide deve ser complementada por outra, a saber, como se decide. $\mathrm{O}$ autor opta pela decisão majoritária como princípio de autoridade, pois segundo ele, esse tipo de princípio de autoridade respeita os indivíduos de dois modos:

\footnotetext{
Primeiro, respeita suas diferenças de opinião sobre justiça e bem comum; não requer que a visão sinceramente mantida de alguém seja depreciada ou silenciada em razão da importância imaginária do consenso. Segundo, incorpora um princípio de respeito com relação a cada pessoa no processo pelo qual decidimos sobre uma visão a ser adotada como nossa, mesmo em face do desacordo (WALDRON, 1999a, p. 109, grifo do autor).
}

Contudo, Waldron reconhece que, em razão das circunstâncias da política, pode haver um eventual descompasso entre teorias dos direitos e teorias da autoridade e, nessa condição, alguém se encontrará submetido a um arranjo social que considera injusto, ainda que esse arranjo seja provisório e possa mudar com as mudanças na própria política. $\mathrm{O}$ exemplo trazido pelo autor é bastante esclarecedor a esse respeito:

Uma pessoa que possui uma completa teoria política - que inclui uma teoria da autoridade tanto quanto teorias da justiça, dos direitos e da política - pode encontrar a si mesma comprometida com uma visão de que a decisão errada pode prevalecer. Sua teoria da justiça, baseada em direitos, pode desaprovar a política $B$ e preferir a política $A$, mas sua teoria da autoridade pode apoiar um procedimento de decisão (desenhado para produzir uma escolha social em face do desacordo sobre, por exemplo, a justiça de $A$ ou $B$ ) que, quando seguida, requer que $B$ seja implementada (WALDRON, 1999a, p. 246). 
Para o autor essa é uma situação natural, não contraditória, haja vista que a pessoa do exemplo está oferecendo, na realidade, respostas para duas questões diferentes, embora complementares. Desse modo, "[q]ue $B$ deveria ser implementado é sua resposta para a questão 'O que devemos fazer dado que discordamos sobre se $A$ ou $B$ é justo?', e que $A$ é a decisão correta é sua própria contribuição ao desacordo que suscitou essa questão" (WALDRON, 1999a, p. 247-8).

Além de não ser contraditória, Waldron considera que também não há uma situação de conflito entre o princípio da autoridade (decisão majoritária) e outros direitos considerados fundamentais, desde que se tenha em mente um desacordo de boa fé. Desse modo, se as pessoas discordam sobre o que os direitos requerem ou o que eles realmente são, o resultado da decisão majoritária irá parecer, ao grupo que apoiou essa decisão, estar de acordo com a justiça e, de modo distinto, para aqueles contrários à decisão majoritária o resultado irá parecer injusto. Ainda que outra teoria da autoridade seja escolhida (monarquia, aristocracia, decisão judicial) e se opte pelo uso da decisão majoritária como princípio de autoridade, o autor entende não fazer sentido falar em conflito entre o princípio da autoridade e os direitos sobre os quais a autoridade deve decidir, pois se há desacordo a respeito da existência ou do significado dos direitos, "não há modo neutro de estabelecer o que exatamente se pressupõe estar competindo com a participação majoritária (ou qualquer outro princípio de autoridade)" (WALDRON, 1999a, p. 248-9).

Para Waldron, questões controversas a respeito de direitos em desacordo devem então ser decididas pelo povo, ou por seus representantes. A retirada desses direitos do debate político, com o intuito de protegê-los, fere o ideal democrático e de autogoverno. A democracia tem, assim, que assumir o desacordo. O autor aceita que "tudo está em disputa na democracia, incluindo os direitos associados com a própria democracia. Ou, certamente, tudo o que está submetido ao desacordo de boa fé está em disputa" (WALDRON, 1999a, p. 303). $\mathrm{Na}$ esteira dessa concepção, a democracia não pode ser avaliada pelos seus resultados, apenas. ${ }^{22}$ Para Waldron, é preciso fazer uma distinção entre "decisões sobre a democracia e decisões tomadas por meios democráticos" (WALDRON, 1999a, p. 292, grifos do autor). Esse é um argumento que leva a discussão para a consideração das responsabilidades dos cidadãos, das legislaturas e das cortes. Se uma decisão é avaliada pelo resultado, parte-se do pressuposto de que, se uma lei aprovada pelo legislativo fere direitos requeridos para uma

\footnotetext{
${ }^{22}$ Esse é um argumento levantado contra Dworkin, mas também poderia ser apresentado a Holmes, que também aceita avaliar a democracia a partir dos resultados, como fica claro quando sustenta uma política de omissão das questões controversas da agenda política justamente para evitar que elas se sobreponham a outras questões sobre as quais é possível haver acordo. Cf. HOLMES, 1988a.
}

Revista da Faculdade de Direito - UFPR, Curitiba, vol. 59, n. 2, p. 143-173, 2014. 
democracia, então essa lei deve ser considerada não democrática e, por conseguinte, a democracia tem um ganho quando uma corte constitucional impede que tal legislação seja aplicada.

Isso apenas reforça a concepção de democracia waldroniana segundo a qual os direitos em desacordo devem ser decididos pelo povo ou por seus representantes. Por essa razão o autor defende que há de fato uma perda para a democracia quando a legislatura eleita de uma sociedade é submetida ao poder judicial. Com relação à atuação do poder judiciário no controle de constitucionalidade das leis, o autor admite o que chama de revisão judicial em sentido fraco, opondo-se à revisão judicial em sentido forte. A distinção entre ambas é que, na primeira hipótese (revisão judicial em sentido fraco), o poder judiciário pode inspecionar a conformidade da legislação aprovada pelo poder legislativo com os preceitos constitucionais e declarar a incompatibilidade entre leis e constituição, devolvendo a matéria para a análise do poder legislativo, mas não pode declarar a invalidade de normas democraticamente aprovadas ou deixar de aplicá-las. ${ }^{23} \mathrm{Na}$ segunda hipótese (revisão judicial em sentido forte), o poder judiciário possui autoridade para declarar a invalidade de normas e/ou deixar de aplicá-las quando reconhecido o conflito ou violação de direitos fundamentais.

\section{CONSIDERAÇÕES FINAIS}

O ponto forte da teoria constitucionalista, tal como estudada a partir das teses de Holmes, é que ela busca encontrar alternativas para que a democracia não se autodestrua ou produza resultados não democráticos, tanto em relação aos indivíduos, quanto às minorias e à sociedade em geral. Essas alternativas são garantidas na medida em que certas questões são retiradas da apreciação popular por meio de decisão majoritária ou fiscalizadas por uma instituição contramajoritária - o poder judiciário.

Um modo de testar os limites de uma teoria, contudo, é averiguar quais seriam as suas respostas a determinados casos-limite. Uma teoria como a de Holmes, cujo critério essencial para a definição da democracia e sua legitimidade se assenta sobre a avaliação do resultado, teria que reconhecer como democrática inclusive uma tecnocracia ou uma monarquia, desde que uma ou outra assegurasse os direitos fundamentais para os indivíduos, para minorias, assim como o bem-estar da sociedade em geral. Nesse caso se percebe que o critério central de uma teoria como a de Holmes desconsidera um dos aspectos que

\footnotetext{
${ }^{23}$ Um clássico exemplo de revisão judicial em sentido fraco é o do Reino Unido, onde as cortes podem revisar a legislação e declarar a incompatibilidade com os direitos fundamentais, mas não podem invalidá-la.

Revista da Faculdade de Direito - UFPR, Curitiba, vol. 59, n. 2, p. 143-173, 2014.
} 
comumente são tomados como essenciais para a noção de democracia, qual seja, a soberania popular e a autonomia coletiva vinculadas à noção de participação popular nos processos de tomada de decisão.

Ademais, quando existe um conjunto de decisões relativas a direitos assegurados formalmente por uma constituição, à qual falta um vínculo com algo que pode ser chamado de vontade popular ou de cultura política de um povo, pode faltar também força normativa para as decisões tomadas, por exemplo, por uma corte constitucional. ${ }^{24}$ Ainda que exista um poder coercitivo que obrigue o cumprimento de certas decisões, caso não haja certo consenso dos membros de uma determinada sociedade em torno daquela decisão, dificilmente se pode esperar que os valores expressos na constituição sejam de fato cumpridos.

Já uma teoria como a de Waldron, cuja proposta abraça o ideal de soberania popular e de supremacia legislativa, pode dar conta de lidar com os problemas de desacordos a respeito da interpretação e ponderação de direitos, principalmente porque é capaz de abarcar e acomodar as mudanças sociais. Ou seja, permite que os desacordos políticos sejam avaliados e reconsiderados por meio do próprio processo político levado a cabo por representantes eleitos democraticamente.

Entretanto, também quanto a esta tese se pode apresentar uma situação limite que expõe seus pontos fracos. Ao admitir que tudo está aberto ao debate e que a legitimidade democrática é garantida essencialmente a partir da ampla participação popular na tomada de decisões, e desde que essas decisões não impeçam futuras decisões populares, Waldron deve admitir que mesmo uma decisão que retire direitos de minorias ainda deve ser considerada democrática. A questão do casamento entre pessoas do mesmo sexo pode ser invocada como um exemplo. Partindo-se do pressuposto de que há um desacordo razoável e de boa fé sobre a existência ou não de um direito ao casamento entre pessoas do mesmo sexo, se um parlamento decidir, seguindo a premissa majoritária, que pessoas do mesmo sexo não possuem o direito ao casamento, ainda assim, segundo a teoria de Waldron, a decisão precisaria ser considerada democrática. Essa mesma questão também poderia ser pensada em relação à retirada de direitos políticos e civis de qualquer minoria.

\footnotetext{
${ }^{24}$ A respeito desse aspecto, Waldron (1999a) também ressalta que constituições e declarações de direitos valem muito pouco sem uma cultura política que as sustentem. Nesse mesmo sentido, Bellamy (2007) questiona até mesmo a efetividade da revisão judicial em casos nos quais o desacordo social é muito forte. Como exemplo, ele evoca o julgamento de Brown vs. Board of Education para mostrar que a vitória por meios legais dificilmente põe fim a uma disputa, a menos que a decisão judicial tenha amplo suporte político. A decisão da Suprema Corte americana que reconheceu a inconstitucionalidade de leis estabelecendo a segregação racial nas escolas públicas ocorreu em 1954. Contudo, o autor ressalta que as mudanças sociais passaram a acontecer apenas dez anos após essa decisão, em razão da atuação contínua do movimento em prol dos direitos civis e da aprovação, pelo Congresso, do Civil Rights Act (1964) e do Voting Rights Act (1965).
}

Revista da Faculdade de Direito - UFPR, Curitiba, vol. 59, n. 2, p. 143-173, 2014. 
Parece haver na teoria de Waldron uma base normativa implícita que não se encontra fundamentada, pois a questão é sempre sobre o significado de um desacordo razoável ou de boa-fé e do quanto essa noção possui força normativa para restringir determinadas posições. Se essa própria noção puder ser objeto de uma decisão majoritária, então, qualquer decisão da maioria pode ser considerada pautada num desacordo razoável. ${ }^{25}$

Além disso, como o próprio Waldron (1999a) reconhece, falta em sua teoria da democracia uma reavaliação da representação política. Sem repensar a democracia representativa, torna-se problemático conferir tanto poder ao legislativo, pois o desenho do legislativo precisa garantir ao mesmo tempo tanto o controle popular em relação aos representantes quanto precisa pensar em meios de desenvolver e qualificar o próprio debate político, pois a vontade política do povo não pode ser tomada simplesmente como algo dado $a$ priori: ela precisa ser fruto de um processo que, por sua vez, crie uma cultura política democrática. O bom funcionamento de uma teoria da democracia constitucional precisa pressupor uma cultura política democrática, a qual deve ser fomentada pelas próprias instituições democráticas. ${ }^{26}$

A crítica formulada por Waldron ao constitucionalismo contemporâneo toca em pontos centrais para se repensar as práticas democráticas e a própria compreensão da democracia constitucional. Contudo, conforme apontado acima, sua própria teoria também apresenta lacunas que podem comprometer demasiadamente a proteção aos direitos fundamentais e ao processo de tomada de decisões democráticas, sem os quais a democracia é impensável nas sociedades contemporâneas. Por essa razão, uma teoria da democracia constitucional precisa dar conta tanto das garantias aos direitos fundamentais quanto da ampliação do espaço de participação popular na tomada de decisões públicas. Em outras palavras, parece ser necessário buscar uma teoria que ao mesmo tempo permita uma ampla discussão democrática, mas que também aponte para garantias de que as decisões democráticas possuam também um conteúdo que possa ser considerado democrático. Essa tarefa, entretanto, extrapola o escopo deste artigo.

\section{REFERÊNCIAS}

ACKERMAN, Bruce. We the people: Vol. 1: Foundations. Cambridge/Massachusetts: Harvard University Press, 1991.

${ }^{25}$ Essa é uma limitação apontada também por Thomas Christiano (2000).

${ }^{26}$ Nesse sentido também é a crítica que János Kis (2009) faz às objeções de Waldron ao pré-compromisso constitucional.

Revista da Faculdade de Direito - UFPR, Curitiba, vol. 59, n. 2, p. 143-173, 2014. 
BELLAMY, Richard. The political form of constitution: The separation of powers, rights and representative democracy. Political Studies, 1996, XLIV.

BELLAMY, Richard; CASTIGLIONE, Dario. Constitutionalism and democracy - political theory and the American Constitution. B.J.Pol.S, 27, 1997, p. 595-618.

- Political Constitutionalism: A republican defense of the constitutionality of democracy. New York: Cambridge University Press, 2007.

BERCOVICI, Gilberto. A constituição dirigente e a crise da teoria da constituição. In: SOUZA NETO, Cláudio Pereira de; BERCOVICI, Gilberto; MORAES FILHO, José Filomeno de; LIMA, Marco Antonio Mont'Alverne Barreto, Teoria da constituição: estudos sobre o lugar da política no direito constitucional. Rio de Janeiro: Lumen Juris, 2003, p. 75150.

Constituição e política: uma relação difícil. In: Lua Nova nº 61, 2004, p. 05-24.

Soberania e constituição: para uma crítica do constitucionalismo. São Paulo: Quartier Latin, 2008.

BERLIN, Isaiah. Dois conceitos de liberdade. In: Estudos sobre a humanidade: uma antologia de ensaios. Editado por Henry Hardy e Roger Hausheer. Prefácio de Noel Annan e introdução de Roger Hausherr. Tradução de Rosaura Eichenberg. São Paulo: Companhia das Letras, 2002.

CHRISTIANO, Thomas. Waldron on law and disagreement. In: Law and Philosophy, Vol. 19, nº 4, Jul. 2000, p. 513-43.

CITTADINO, Gisele. Judicialização da política, constitucionalismo democrático e separação de poderes. In: Luiz Werneck Vianna (Org). A democracia e os três poderes no Brasil. Belo Horizonte: Editora UFMG, 2002, p. 17-42.

DWORKIN, Ronald. Constitutionalism and democracy. European Journal of Philosophy. 3:1, 1995, p. 2-11.

O direito da liberdade: a leitura moral da Constituição norte-americana. Tradução por Marcelo Brandão Cipolla. São Paulo: Martins Fontes, 2006.

ELSTER, Jon. Ulises y las Sirenas: estudios sobre la racionalidad e irracionalidad. Tradución de Juan José Utrilla. México: Fondo de Cultura Económica, 1989.

ELY, John Hart. Democracia y desconfianza: una teoría del control constitucional. Traductora Magdalena Holguín. Santafé de Bogotá: Siglo del Hombre Editores, 1997.

FIORAVANTI, Maurizio. Constitución: de la antigüedad a nuestros días. Trad. Manuel Martinez Neira. Madrid:Trotta, 2001.

GORDON, Scott. Controlling the state: constitutionalism from ancient Athens to today. Cambridge, Massachusetts, and London, England: Harvard University Press, 1999. 
HAMILTON, Alexander; JAY, John; MADISON, James. The federalist papers. Edited by Isaac Kramnick. London: Penguin Books, 1987.

HAYEK, F. A. The constitution of liberty: the definitive edition. Edited by Ronald Hamowy. Chicago: Chicago University Press, 2011.

HOLMES, Stephen. Gag rules or the politics of omission. In: J. Elster / R. Slagstad (Orgs.), Constitutionalism and democracy. Cambridge: Cambridge University Press, 1988a, p. 19-58.

Precommitment and the paradox of democracy. In: J. Elster/ R. Slagstad (Orgs.), Contitutionalism and democracy. Cambridge: Cambridge University Press, 1988b, p. 195240.

JEFFERSON, Thomas. The portable Thomas Jefferson. Edited by Merril D. Peterson. Penguin Books, 1977.

KIS, János. Constitutional precommitment revisited. Texto apresentado no Legal, Political and Social Philosophy Colloquium realizado na New York University, 2009. Disponível em: <http://www.law.nyu.edu/ecm_dlv4/groups/public/@nyu_law_website_academics_colloqui a_legal_political_and_social_philosophy/documents/documents/ecm_pro_062725.pdf>.

Acesso em: 19 dez. 2011.

KOZICKI, Katya; BARBOZA, Estefânia Maria de Queiroz. Judicialização da política e controle judicial de políticas públicas. In: Revista Direito $G V$, vol. 8 n 1 , jan-jun 2012, p. 5986.

KRAMER, Larry D. The people themselves: popular constitutionalism and judicial review. New York: Oxford University Press, 2004.

McILWAIN, C.H. Constitutionalism: ancient and modern. Indianapolis: Liberty Fund, 2007.

MOHNHAUPT, Heinz; GRIMM, Dieter. Costituzione: storia di un concetto dall'Antichità a oggi. Edizione italiana a cura di Mario Ascheri e Simona Rossi. Roma: Carocci editore, 2008.

MOREIRA, Luiz. A constituição como simulacro. Rio de Janeiro: Lumen Juris Editora, 2007. Judicialização da política (Org). São Paulo: 22 Editorial, 2012.

NOBRE, Marcos; RODRIGUES, José Rodrigo. Judicialização da política: déficits explicativos e bloqueios normativistas. In: Novos Estudos, nº 91, novembro 2011, p. 5-20.

PAINE, Thomas. The rights of man, part I. In: Paine: Political Writings. Edited by Bruce Kuklick. Cambridge: Cambridge University Press, 2009.

PINZANI, Alessandro. Democracia versus tecnocracia: apatia e participação em sociedades complexas. In: Lua Nova, nº 89, 2013, p. 135-68.

RAWLS, John. A theory of justice. Cambridge, Massachusetts: Harvard University Press, 1999. 
Justice as fairness: political not metaphysical. In: Philosophy and public affairs, vol. $14, \mathrm{n}^{\mathrm{o}} 3$ (Summer, 1985), p. 223-51.

SAJÓ, András. Limiting government: an introduction to constitutionalism. Budapest, Hungary, New York, USA: Central European University Press, 1999.

SPINOZA, Benedictus (Baruch) de. Tratado Político. Trad. N. de Paula Lima. São Pulo: Ícone, 1994.

TUSHNET, Mark. Taking the constitution away from the courts. Princeton, New Jersey: Princeton University Press, 1999.

UNGER, Roberto Mangabeira. What should legal analysis become? London/NewYork: Verso, 1996.

WALDRON, Jeremy. A right-based critique of constitutional rights. In: Oxford Journal of Legal Studies.Vol. 13, N 1, 1993, p. 18-51.

Constitutionalism - a skeptical view. In: T. Christiano / J. Christman (orgs.). Contemporary debates on political philosophy. Malden, Massachusetts: Blackwell Publishing, 2009, p. 267-82.

Law and disagreement. New York: Oxford University Press, 1999a.

. Precommitment and disagreement. In: L. Alexander, (org.). Constitutionalism. Philosophical foundations. Cambridge: Cambridge University Press, 1998, p. 271-99. $1346-406$

The core of the case against judicial review. The Yale Law Journal, 115, 2006, p. . The dignity of legislation. New York: Cambridge University Press, 1999b. 


\title{
JEREMY WALDRON'S CRITICISM TO CONTEMPORARY CONSTITUTIONALISM
}

\begin{abstract}
This paper presents and discusses Jeremy Waldron's criticism of contemporary constitutionalism - namely against constitutional theories that focus the discussion of constitutional democracy on protection of fundamental rights and its withdrawal from the political debate. To these ends, first are presented the constitutional arguments that Waldron opposes, after which appear his criticisms of constitutionalist thesis, as well as his proposals for reconciling the constitutional ideal and democracy. Finally, will be made an assessment about the limits of each of the theories under discussion.
\end{abstract}

KEYWORDS: Constitutionalism. Democracy. Jeremy Waldron.

Recebido em: 16 de março de 2014

Aprovado em: 13 de abril de 2014 